\title{
MODEL ORTODOKSI-ORTOPRAKSI-ORTOPATI: Usulan Model Berteologi sebagai Cara Hidup Kaum Injili di Dunia Pascakebenaran*
}

\author{
Hendra Yohanes **
}

\begin{abstract}
Abstrak: Era pascakebenaran (post-truth) ditandai dengan pudarnya relevansi kebenaran dan verifikasi fakta digantikan dengan preferensi pribadi dan tarikan emosional. Dalam konteks pemilihan umum Indonesia pada tahun 2014 dan 2019, berbagai hoaks bernuansa SARA yang bermunculan mengancam kohesi sosial di bangsa ini. Dengan demikian, pascakebenaran tidak lagi sekadar menjadi isu di kalangan akademisi, tetapi juga dipertunjukkan secara masif di ruang publik. Bagaimana kaum injili menanggapi problematika pascakebenaran yang kompleks ini? Artikel ini mengusulkan sebuah model teologi yang integratif dalam menghadapi tantangan-tantangan di dunia pascakebenaran, yakni model Ortodoksi-Ortopraksi-Ortopati sebagai cara hidup kaum injili. Di akhir artikel ini, model berteologi ini diimplementasikan untuk menanggapi problematika post-truth yang berkembang dewasa ini di Indonesia.
\end{abstract}

Abstract: The post-truth era is indicated by the eclipsing of the relevance of truth and fact verification replaced by personal preference and emotional appeal. In the context of Indonesia's national elections in 2014 and 2019, multitude of hoaxes emerged with respect to tribal affiliations, religion, race and societal groups and threatened social cohesion in this nation. Correspondingly, post-truth not merely an issue in the academia but also is massively demonstrated in the public sphere.

* Artikel ini merupakan pemenang pertama Lomba Karya tulis Teologi (LKTT) Sekolah Tinggi Teologi Amanat Agung.

** Penulis adalah mahasiswa program Magister Teologi (M.Th.) di STT SAAT, Malang. Penulis dapat dihubungi melalui email: hendr4y0@gmail.com. 
How do the evangelicals respond to the complex problem of post-truth? This article proposes an integrative theological model in facing challenges in a post-truth world, namely the Orthodoxy-OrthopraxisOrtopathy Model as the evangelicals' way of life. At the end of this article, this theological model implemented to respond post-truth problems that recently emerged in Indonesia.

Kata-kata Kunci: post-truth, pascakebenaran, model berteologi, injili, cara hidup, ortodoksi, ortopraksis, ortopati.

\section{Pendahuluan}

Pada November 2016, Kamus Oxford menetapkan kata "posttruth" sebagai "word of the year." ${ }^{1}$ Kata yang diterjemahkan menjadi "pasca-kebenaran" ini bukan dimaksudkan telah melewati kebenaran secara temporal melainkan dalam pengertian bahwa kebenaran telah memudar (eclipsed) atau tidak relevan lagi. ${ }^{2}$ Emosi, preferensi, dan selera lebih diutamakan dan berpengaruh dalam berargumentasi daripada memperhatikan verifikasi fakta, akurasi data, dan validitas informasi. Istilah post-truth pertama kali diperkenalkan Steve Tesich dalam esai di majalah The Nation (1992) untuk mengkritik kebijakan Amerika Serikat, yang memberikan informasi yang tidak benar kepada masyarakat dan memanfaatkan situasi masyarakat yang hanya

1. Lee C. Mclntyre, Post-Truth, The MIT Press Essential Knowledge Series (Cambridge: MIT Press, 2018), 1. Kamus Oxford mendefinisikan demikian, "relating to or denoting circumstances in which objective facts are less influential in shaping public opinion than appeals to emotion and personal belief" (seperti dikutip dari McIntyre, Post-Truth, 5).

2. McIntyre, Post-Truth, 5. 
mendengarkan informasi yang diinginkan. ${ }^{3}$ Fenomena ini mulai mendunia sejak tahun 2016 pada referendum Brexit dan pemilihan umum Amerika Serikat yang dipenuhi dengan penyebaran berita bohong dan sangat memengaruhi pemilih.

Fenomena serupa juga merebak menjelang pemilihan umum Indonesia pada tahun 2014 dan 2019, di mana beredar berbagai hoax bernuansa SARA yang mengancam kohesi sosial di Indonesia. ${ }^{4}$ Pascakebenaran tidak lagi sekadar menjadi isu di kalangan akademisi, tetapi juga merebak di ruang publik, di mana kepentingan politik dan partisipasi sosial-kultural dipertunjukkan secara masif dan latah. Di Indonesia sendiri, tidak hanya kalangan elit politik yang mengujarkan terminologi post-truth dan hoax, melainkan warganet (netizen) dan masyarakat di tataran akar rumput juga gandrung dengan tren ini. Fenomena ini tidak hanya menjangkiti ranah politik tetapi juga ranah medis, sosial-kultural, religius, dan lain sebagainya. ${ }^{5}$

3. Petrus R. Golose, "Strategi Penanganan Firehose of Falsehood pada Era Post-Truth (Kajian dalam Rangka Menyukseskan Pemilu 2019)," Jurnal Ilmu Kepolisian 13/1 (2019): 8.

4. "The War on Hoaxes," The Jakarta Post, 2018, diakses 14 September 2019, https://www.thejakartapost.com/academia/2018/10/09/the-war-onhoaxes.html.

5. Contoh di bidang politik adalah hoax yang diumbar Ratna Sarumpaet. Ratna mengklaim ia dianiaya oleh tiga orang tak dikenal pada 21 September 2019 di Bandung. Kemudian, ia tidak melapor kepada polisi, tetapi malah kepada teman-teman politikusnya dan calon presiden yang didukungnya sehingga digelar konferensi pers yang mengutuk keras penganiayaan yang diklaim Ratna ("Jebakan Hoaks Ratna Sarumpaet," Tempo, 2018, diakses 14 September 2019, https://kolom.tempo.co/read/1133717/jebakan-hoaksratna- sarumpaet). Berita bohong ini memenuhi kriteria firehose of falsehood, karena disebarkan secara berulang melalui media berita resmi, media sosial 
Dalam karya tulis ini, penulis mengupas masalah-masalah mendasar yang mendefinisikan pascakebenaran, termasuk: pengabaian fakta, hoax di media sosial, serta hubungan dengan pascamodernisme. Tesis yang diajukan penulis adalah problematika pascakebenaran yang kompleks ini perlu ditanggapi dengan metode berteologi yang komprehensif guna menjawab isu-isu yang bertautan dengan pascakebenaran dan model berteologi yang ditawarkan penulis adalah model Ortodoksi-Ortopraksi-Ortopati sebagai cara hidup kaum injili. Penulis menyadari kompleksitas problematika post-truth dan mencoba mengurainya menjadi tiga bagian dengan memakai kerangka Lee McIntyre (seorang pakar filsafat dan sejarah sains), antara lain: (1) epistemologi, penyangkalan sains, dan bias kognitif; (2) berita bohong dan dinamika media sosial; (3) hubungan dengan pascamodernisme dan relativisme. Selanjutnya, penulis menguraikan secara ringkas metode berteologi dan identitas teologis injili serta mengusulkan sebuah model berteologi, yakni model Ortodoksi-Ortopraksi-Ortopati. Kemudian, sebagai penutup dari karya tulis ini, penulis menawarkan implementasi

hingga grup chat (Golose, "Strategi," 11). Sedangkan, berita bohong di bidang medis adalah vaksin Measles-Rubella menyebabkan kondisi anak yang diimunisasi menjadi memprihatinkan. Selengkapnya, lih. Christiany Juditha, "Literasi Informasi Melawan Hoaks Bidang Kesehatan di Komunitas Online," Jurnal IImu Komunikasi 16/1 (Juni 2019): 83-85. Fenomena serupa telah terjadi di Inggris di mana vaksin anak dikaitkan secara keliru dengan autisme (lih. Stephan Lewandowsky, Ullrich K. H. Ecker, dan John Cook, "Beyond Misinformation: Understanding and Coping with the 'Post-truth' Era," Journal of Applied Research in Memory and Cognition [2017]: 7; Daniel J. Levitin, Weaponized Lies: How to Think Critically in the Post-Truth Era, Google Play Books [Dutton, 2017], 170-71; McIntyre, Post-Truth, 82-83). 
model berteologi ini sebagai cara hidup kaum injili dalam menanggapi problematika post-truth yang berkembang dewasa ini di Indonesia.

\section{Mengupas Masalah Post-Truth}

Apa itu "kebenaran"? Aristotle mendefinisikan demikian, "To say of what is that it is not, or of what is not that it is, is false, while to say of what is that it is, and of what is not that it is not, is true." ${ }^{6}$ Kebenaran dan aktivitas menyatakan kebenaran sangat penting bagi institusi sains, hukum, dan pendidikan serta merupakan infrastruktur budaya di mana manusia dapat menjalani kehidupan, bermasyarakat, membangun peradaban, dan memahami dunia. ${ }^{7}$ Namun, era pascakebenaran yang merupakan "era irasionalitas yang disengaja" (a era of willful irrationality) justru menunggangbalikkan seluruh pencapaian manusia dalam sejarah. ${ }^{8}$ Gagasan post-truth yang mengutamakan tentang perasaan lebih penting ketimbang fakta-fakta memiliki konsekuensikonsekuensi yang justru berbahaya bagi kehidupan bermasyarakat dan peradaban. ${ }^{9}$ Tetapi, mengapa pascakebenaran dapat muncul dan merebak sedemikian luas menjadi tren kontemporer? McIntyre menjelaskan demikian:

6. Julian Baggini, A Short History of Truth: Consolations for A Post-Truth World, edisi Kindle (London: Quercus, 2017), loc. 65.

7. Lih. Sharon Rider dan Michael A. Peters, "Post-truth, Fake News: Viral Modernity and Higher Education," dalam Post-Truth, Fake News, ed. Michael A. Peters dkk. (Singapura: Springer, 2018), 3.

8. Lih. Levitin, Weaponized Lies, 13.

9. McIntyre, Post-Truth, 13. 
Someone does not dispute an obvious or easily confirmable fact for no reason; he or she does so when it is to his or her advantage. When a person's beliefs are threatened by an "inconvenient fact," sometimes it is preferable to challenge the fact. This can happen at either a conscious or unconscious level (since sometimes the person we are seeking to convince is ourselves), but the point is that this sort of post-truth relationship to facts occurs only when we are seeking to assert something that is more important to us than the truth itself. Thus post-truth amounts to a form of ideological supremacy, whereby its practitioners are trying to compel someone to believe in something whether there is good evidence for it or not. And this is a recipe for political domination. ${ }^{10}$

Jadi, pascakebenaran berhubungan dengan penolakan terhadap fakta, khususnya fakta-fakta yang dianggap tidak menyenangkan, sebagai semacam supremasi ideologis yang diyakini tanpa mendasarkannya kepada bukti yang baik atau tidak.

Epistemologi, Penyangkalan Sains, dan Bias Kognitif

Post-truth dapat dipandang sebagai suatu ketidakpedulian terhadap kebenaran (an indifference toward truth) yang dipasangkan dengan penekanan terhadap tarikan emosi, prasangka, dan faktorfaktor lainnya yang sering dianggap tidak dapat diandalkan secara epistemik. ${ }^{11}$ Menurut McIntyre, kemunculan pascakebenaran tidak

10. McIntyre, Post-Truth, 13.

11. Ulf Zackariasson, "Introduction: Engaging Relativism and PostTruth," dalam Relativism and Post-truth in Contemporary Society: Possibilities and Challenges, ed. Mikael Stenmark, Steve Fuller, dan Ulf Zackariasson (New York: Springer, 2018), 5. 
dimulai sejak tahun 2016 tetapi berakar pada debat akademis tentang kemustahilan kebenaran objektif yang dipakai untuk menyerang otoritas sains. ${ }^{12}$ Akibatnya, kalangan awam mempertanyakan baik motif maupun kompetensi ilmuwan yang melahirkan "penyangkalan atas sains" (science denialism). ${ }^{13}$ Penjelasan terbaik para ilmuwan dipandang tidak dapat ditawarkan sebagai kebenaran tetapi hanya keyakinan yang dijustifikasi berdasarkan bukti yang ditemukan, sehingga penalaran ilmiah dieksploitasi oleh orang-orang yang merasa diri "ilmuwan sejati" yang tidak mengecualikan kemungkinan kebenaran teori-teori alternatif. ${ }^{14}$ Contohnya, isu perubahan iklim yang dianggap bukan disebabkan oleh aktivitas manusia, karena para ilmuwan belum mencapai konsensus penuh mengenai korelasi antara perubahan iklim dengan ulah manusia. ${ }^{15}$

Menurut McIntyre, realitas pascakebenaran dibentuk dengan penggunaan fakta-fakta secara selektif yang mendukung posisi seseorang dan menolak sepenuhnya fakta-fakta yang tidak sesuai dengan pandangannya, dengan tujuan mencapai hasil politik tertentu tanpa terlalu mempedulikan caranya, sehingga fakta-fakta menjadi lebih subordinate dibanding dengan opini-opini. ${ }^{16}$ Alhasil, pascakebenaran

12. Mclntyre, Post-Truth, 14.

13. Mclntyre, Post-Truth, 18.

14. Lih. Mclntyre, Post-Truth, 19-20.

15. Survei terhadap 4000 jurnal ilmiah pada tahun 2013 menegaskan 97\% ilmuwan menyetujui bahwa perubahan iklim disebabkan ulah manusia, tetapi hanya $27 \%$ dari orang dewasa Amerika dalam jajak pendapat publik yang menyetujui mayoritas ilmuwan sepakat mengenai hal ini. Bdk. Mclntyre, PostTruth, 30, 70; Lewandowsky, Ecker, dan Cook, “Misinformation,” 11.

16. Lih. Mclntyre, Post-Truth, 34. 
dapat dipandang bahwa para penggerak politik telah menciptakan epistemologi alternatif yang tidak memerlukan bukti-bukti pendukung sebagai standar konvensional. ${ }^{17}$ Menurut penulis, bahkan pencipta epistemologis alternatif tidak hanya tokoh politik dengan agenda politiknya, tetapi setiap pihak yang memiliki kepentingan tertentu dan menjalankan propaganda lewat epistemologi alternatif seperti ini. Contohnya, para pemimpin perusahaan tembakau pada tahun 1953 mendirikan Tobacco Industry Research Committee untuk melemparkan keraguan terhadap konsensus ilmiah bahwa merokok menyebabkan kanker dan berusaha meyakinkan media untuk memaparkan sisi lain dari risiko tembakau secara berimbang kepada publik. ${ }^{18}$

McIntyre juga bertolak dari temuan riset psikologi sosial mengenai bias kognitif bahwa manusia tidak serasional yang diduga. Manusia memiliki ketegangan psikis ketika mempercayai dua hal yang saling bertentangan satu sama lain sehingga memiliki tendensi untuk diyakinkan kembali oleh orang-orang di sekitarnya yang memegang pandangan yang sama. ${ }^{19}$ Ketika kita merasakan ketidaknyamanan secara psikis, kita terdorong untuk mencari cara mereduksinya dengan mengakomodasi kepercayaan-kepercayaan kita sesuai dengan perasaan-perasaan kita (motivated reasoning) dan menafsirkan informasi sedemikian rupa agar memberikan konfirmasi terhadap kepercayaan-kepercayaan yang telah dimiliki sebelumnya (confirmation

17. Lewandowsky, Ecker, dan Cook, “Misinformation,” 13-14.

18. Mclntyre, Post-Truth, 21-25.

19. Mclntyre, Post-Truth, 36-38. 
bias)..$^{20}$ Dengan kata lain, orang-orang merasa bahwa keyakinannya adalah benar, merasa lebih mengetahui informasi yang valid, dan melakukan penalaran yang cenderung menguatkan keyakinannya daripada mengkritisinya sesuai fakta-fakta yang ada. ${ }^{21}$

Berita Bohong (Hoax) dan Dinamika Media Sosial

Dunia internet telah mencampurbaurkan antara informasi yang benar dengan yang keliru (misinformation) sehingga sukar dibedakan. ${ }^{22}$ Berita palsu (fake news) tidak sekadar berita yang salah tetapi secara sengaja (deliberately, intentionally) dibuat untuk memalsukan konten berita dengan motif tertentu (propaganda) dan membuat orang lain percaya sekalipun ia mengetahui bahwa berita itu sesungguhnya tidak benar. ${ }^{23}$ Masyarakat pascakebenaran sangat mudah mengakses berita yang disebarkan melalui media sosial dan tergesa-gesa menyebarkan kepada orang lain tanpa memverifikasi kebenaran berita itu terlebih dahulu. ${ }^{24}$ Hoax dan misinformation yang semarak pada era pascakebenaran berandil membentuk opini publik dan memengaruhi pengambilan keputusan secara negatif. ${ }^{25}$

20. Mclntyre, Post-Truth, 45.

21. Bdk. Golose, "Strategi," 11.

22. Levitin, Weaponized Lies, 18.

23. Mclntyre, Post-Truth, 105, 112.

24. Barna Group, "The Truth about a Post-Truth Society: Barna Identifies Five Reasons the World Is No Longer in Agreement about Anything," dalam Barna Trends 2018: What's New and What's Next at the Intersection of Faith and Culture (Grand Rapids: Baker, 2017), 119-20.

25. Bdk. Golose, "Strategi," 11. 
Pascamodernisme dan Relativisme

Dua tesis dari pascamodernisme adalah tidak ada kebenaran objektif dan klaim kebenaran tidak lebih daripada refleksi dari ideologi politik yang dimiliki seseorang. ${ }^{26}$ Os Guinness mendeskripsikan pascamodernisme demikian, "There is no truth; only truths. There is no grand reason; only reasons. There is no privileged civilization (or culture, belief, norm and style); only a multiplicity of cultures, beliefs, norms and styles." ${ }^{27}$ Salah satu aspek pascamodernisme berkenaan dengan teks dan bahasa adalah dekonstruksi sebagai metode kritik yang menyatakan bahwa identitas dan maksud penulis teks tidak relevan untuk penafsiran teks sebab tidak ada makna pasti di dalamnya. ${ }^{28}$ Alhasil, gagasan kebenaran diserang dengan dekonstruksi dan banyak jawaban-jawaban yang dimunculkan dengan interpretasi yang membawa asumsi dan latar belakang penafsir. ${ }^{29}$ Selain itu, Foucault menyatakan bahwa kebenaran berhubungan dengan kekuasaan (power), sebab "kebenaran" dapat menyokong sistem represi dengan menentukan standar yang memaksa masyarakat untuk mematuhinya. ${ }^{30}$ Implikasinya, kebenaran dianggap bersifat fasis dan semua wawasan dunia sama-sama dianggap valid. ${ }^{31}$ Dalam dunia pascakebenaran, kebohongan bukan lagi tentang

26. McIntyre, Post-Truth, 127.

27. Seperti dikutip dari Alister E. McGrath, A Passion for Truth: The Intellectual Coherence of Evangelicalism (Leicester: Apollos, 1997), 180.

28. McGrath, Passion, 186.

29. McIntyre, Post-Truth, 125.

30. McGrath, Passion, 193.

31. McGrath, Passion, 192. 
mengubah keyakinan orang-orang tetapi menerapkan kekuasaan. ${ }^{32}$ Namun, pandangan Foucault ini sendiri mengandung keyakinan bahwa represi itu salah, sehingga sebenarnya ia berkomitmen kepada nilai moral objektif untuk dapat menilai bahwa penggunaan kekuasaan yang dipaksakan itu tidak adil. ${ }^{33}$

Mengenai hubungan kondisi post-truth dengan pascamodernisme, Zackariasson menjelaskan demikian:

The frustrating conclusion need not be the extremely skeptical view that there is no truth: we can just as well-and equally frustrating to many-say that there are actually (too) many truths, many different local perspectives and approaches that all can claim a limited validity, but as far as anyone can tell, there is no God's eye point of view from which to adjudicate between them. ${ }^{34}$

Relativisme yang ditimbulkan pascamodernisme membuat semakin sulit untuk mengklaim kebenaran yang absolut dan superior terhadap klaimklaim kebenaran yang ada. Jika kebenaran itu tidak ada, yang ada hanyalah perspektif-perspektif, dan berita hanyalah ekspresi politis, bagaimana kita dapat sungguh memiliki pengetahuan yang benar? ${ }^{35}$ Lalu, bagaimana klaim kebenaran kekristenan dapat diperhitungan dengan serius di dunia pascamodern? Tantangan pascamodernisme adalah tidak seorang pun berdiri di posisi epistemologis yang lebih

32. Lewandowsky, Ecker, dan Cook, “Misinformation,” 26.

33. McGrath, Passion, 194-96.

34. Zackariasson, "Engaging Relativism," 3.

35. Mclntyre menyimpulkan pascakebenaran disebabkan oleh pascamodernisme (Mclntyre, Post-Truth, 150). 
unggul dan relativisme juga tidak terhindarkan, sehingga teologi memang tidak didiskualifikasi tetapi juga tidak diberikan keistimewaan daripada posisi lainnya. ${ }^{36} \mathrm{Di}$ tengah lautan kebenaran-kebenaran sebagai perspektif-perspektif alternatif dan seolah tidak seorang pun yang memiliki sauh untuk mengklaim memiliki Kebenaran, ${ }^{37}$ apakah orang Kristen hanya akan terombang-ambing? Penulis menanggapi problematika pascakebenaran ini dengan mengusulkan sebuah model berteologi kaum injili.

\section{Metode Berteologi dan Model Ortodoksi-Ortopraksi-Ortopati}

Metode Teologi dan Identitas Injili

Metode teologi mungkin tidak mendapat banyak perhatian daripada ilmu teologi itu sendiri. ${ }^{38}$ Dalam berteologi, seseorang berada dalam latar belakang kehidupan yang spesifik. Oleh karena itu, peran latar belakang teolog sangat berpengaruh terhadap cara dan praanggapan yang dibawanya dalam berteologi, termasuk tradisi komunitas iman dari mana ia berasal dan bertumbuh serta konteks sosial-kultural di mana ia tinggal. ${ }^{39}$ Seluruh komunitas-komunitas Kristen memiliki tradisi sehingga sangat problematis jika seseorang mengklaim

36. Dan R. Stiver, "Theological Method," dalam The Cambridge Companion to Postmodern Theology, ed. Kevin J. Vanhoozer, Cambridge Companions to Religion (Cambridge: Cambridge University Press, 2003), 174-75.

37. Bdk. McGrath, Passion, 188.

38. Paul Allen, Theological Method: A Guide for the Perplexed (New York: Continuum, 2012), 1.

39. Bdk. Howard W. Stone dan James O. Duke, How to Think Theologically, ed. ke-2. (Minneapolis: Fortress, 2006), 46. 
ia berteologi bebas dari tradisinya yang merupakan konteks yang memengaruhi bagaimana ia menafsirkan Alkitab dan berteologi. ${ }^{40}$ Penulis bertumbuh di dalam lingkungan tradisi gereja injili dan teologi Reformed yang membentuk bagaimana penulis berteologi. ${ }^{41}$

Kelahiran gerakan injili dapat ditelusuri sejak pertengahan abad ke-18 dari pengaruh para tokoh yang merindukan kebangunan kembali gereja-gereja di Eropa Utara dan Amerika Utara, seperti: George Whitefield, John Wesley, dan Jonathan Edwards. ${ }^{42}$ David Bebbington mengidentifikasi empat unsur penting dari evangelikalisme, yakni penekanan terhadap "lahir baru" (conversionism), kebersandaran pada otoritas Alkitab (biblicism), kepedulian untuk membagikan iman dalam misi dan penginjilan (activism), dan penekanan tentang karya pengurbanan Kristus di salib (crucicentrism). ${ }^{43}$ Sedangkan, John G.

40. Bdk. Mary M. Veeneman, Introducing Theological Method: A Survey of Contemporary Theologians and Approaches (Grand Rapids: Baker Academic, 2017), 13; Stiver, "Method," 176.

41. Evangelikalisme menunjukkan kesinambungan teologis dengan teologi Reformasi, terutama mengenai otoritas Alkitab (Alister E. McGrath, "Evangelical Theological Method: The State of the Art," dalam Evangelical Futures: A Conversation on Theological Method, ed. John G. Stackhouse [Grand Rapids: Baker, 2000], 28-29).

42. Timothy Larsen, "Defining and Locating Evangelicalism," dalam The Cambridge Companion to Evangelical Theology, ed. Timothy Larsen dan Daniel J. Treier, Cambridge Companions to Religion (Cambridge: Cambridge University Press, 2007), 1; Mark A. Noll, Skandal Pemikiran Injili, terj. Sudi Ariyanto (Surabaya: Momentum, 2008), 8-9.

43. Lih. Noll, Skandal, 9. "Pentagon evangelikalisme" dari Larsen mencakup: Protestan ortodoks, tradisi jejaring Kristen global yang muncul sejak abad ke-18, biblisisme, krusisentrisme serta karya Roh Kudus dalam mempertobatkan orang percaya (konversionisme) dan memampukan proklamasi Injil (aktivisme). Lih. Larsen, “Defining,” 1-2. 
Stackhouse mendefinisikan "evangelikal" dengan lima karakteristik, yaitu: mengutamakan Injil Yesus Kristus, otoritas Alkitab sebagai Firman Allah, pertobatan, misi, dan transdenominasionalisme. ${ }^{44}$ Alister McGrath mendaftarkan enam keyakinan mendasar evangelikalisme, yaitu: otoritas Alkitab sebagai sumber pengetahuan tentang Allah dan panduan bagi kehidupan kristiani; kemuliaan Yesus Kristus sebagai Tuhan dan Juruselamat bagi manusia berdosa; ketuhanan Roh Kudus; kebutuhan pertobatan pribadi; prioritas penginjilan secara perorangan maupun keseluruhan gereja; serta pentingnya komunitas kristiani bagi asupan, persekutuan dan pertumbuhan rohani. ${ }^{45}$ Kepercayaan (belief), praksis, dan nilai-nilai di dalam identitas injili ini yang memengaruhi metode berteologi penulis.

44. John G. Stackhouse, "Evangelical Theology Should Be Evangelical," dalam Evangelical Futures: A Conversation on Theological Method, ed. John G. Stackhouse (Grand Rapids: Baker, 2000), 40-43. Transdenominasionalisme adalah kesepakatan terhadap empat karakteristik yang tidak dapat ditawartawar dari pengakuan dan praktik Kristen serta memberikan ruang bagi komunitas-komunitas Kristen untuk berbeda dalam hal-hal yang sekunder dan non-esensial (Stackhouse, "Evangelical," 42). Karakter transdenominasional berarti evangelikalisme tidak terkungkung oleh salah satu denominasi atau pun rincian tata gereja, melainkan mendukung "penyerbukan silang" antara berbagai institusi injili termasuk: seminari, institusi riset, penerbit, dan jurnal (Alister E. McGrath, Evangelicalism \& the Future of Christianity [Downers Grove: InterVarsity, 1995], 82-83, 79-80). Namun, ini tidak menafikan fakta bahwa ada tokoh dari masing-masing denominasi yang berupaya melepaskan denominasinya dari evangelikalisme sebagai payung bersama. Contohnya, Archer yang hendak melepaskan label "injili" supaya dapat berteologi secara autentik sebagai kaum Pentakosta (Kenneth J. Archer, "A Pentecostal Way of Doing Theology: Method and Manner," International Journal of Systematic Theology 9/3 [Juli 2007]: 304).

45. McGrath, Evangelicalism, 55-56. 
Di kalangan injili, terdapat persetujuan umum bahwa kaum injili tidak memberikan perhatian yang memadai kepada metode berteologi (theological method), sehingga banyak kaum injili yang tidak merasa perlu mengekspresikan secara formal tentang metode berteologi. ${ }^{46}$ Walaupun demikian, ini tidak berarti kaum injili tidak memiliki metode teologi sama sekali. Setidaknya, sumber-sumber teologi dipergunakan kalangan injili di dalam mengartikulasikan keyakinan teologis dan menjalani praksis kehidupan sebagai kaum injili. Secara historis, teologi Kristen berkembang dengan menggunakan sumber-sumber teologi seperti: Alkitab, akal budi, tradisi, dan pengalaman. ${ }^{47}$ Memang kaum injili mengutamakan Alkitab, khotbah yang baik, dan literasi Alkitab; tetapi kritik yang sering diberikan adalah kaum injili terlalu berfokus kepada Alkitab sampai-sampai tidak mempergunakan secara serius sumber-sumber teologi lainnya. ${ }^{48}$ Berkaitan dengan biblisisme, Luther sendiri tidak memaksudkan prinsip sola scriptura untuk membatasi Alkitab sebagai satu-satunya sumber teologi, melainkan Alkitab merupakan sumber utama bagi teologi (the chief source of theology) dan merupakan norma yang berotoritas atas ketiga sumber lainnya. ${ }^{49}$ Jadi, penulis berpandangan bahwa kaum injili tetap dapat merangkul ragam tradisi kekristenan, akal budi, dan pengalaman sebagai sumber-sumber

46. McGrath, "Evangelical," 15-16.

47. Keempat sumber berteologi ini sering diistilahkan "kuadrilateral Wesley." Bdk. Allen, Method, 8; Veeneman, Introducing, 10, 13; Dan R. Stiver, Life Together in the Way of Jesus Christ: An Introduction to Christian Theology (Waco: Baylor University Press, 2009), 52.

48. Stackhouse, "Evangelical," 46.

49. Lih. Veeneman, Introducing, 8; Stiver, Life, 52-56. 
teologi tanpa mengabaikan keutamaan otoritas Alkitab sebagai ciri biblisisme dari teologi injili.

Usulan Model Berteologi: Ortodoksi-Ortopraksi-Ortopati

Lalu, bagaimana model berteologi kaum injili pada era pascakebenaran ? $^{50}$ Dalam tulisan ini, penulis menawarkan sebuah model berteologi sebagai cara kehidupan (way of life) kaum injili dengan melibatkan kepercayaan yang benar (orthodoxy), praksis kehidupan yang memancarkan kebaikan sebagai pengikut Kristus (orthopraxy), dan afeksi yang memancarkan keindahan Kristus (orthopathy). Secara ringkas, penulis menamai model berteologi ini sebagai "model Ortodoksi-Ortopraksi-Ortopati." Meskipun model berteologi ini bukan milik kaum injili secara eksklusif, tetapi penulis memandang bahwa model ini dapat dipakai menjadi sarana untuk berteologi oleh kaum injili. ${ }^{51}$ Karena itu, di dalam pemaparan berikut ini, penulis akan meng-

50. Untuk survei metode teologi injili secara umum, lih. Veeneman, Introducing, bab 5.

51. Menurut Woodbridge, model ini diusulkan oleh Steven J. Land dari kalangan Wesleyan-Pentakostal yang menegaskan spiritualitas sebagai integrasi antara kepercayaan, praktik, dan afeksi (N. B. Woodbridge, "Living Theologically-Towards A Theology of Christian Practice in Terms of the Theological Triad of Orthodoxy, Orthopraxy and Orthopathy as Portrayed in Isaiah 6:1-8: A Narrative Approach," HTS Teologiese Studies/Theological Studies 66/2, Art. \#807 [2010]: 3). Menurut Land, ortodoksi dan ortopraksi perlu diintegrasikan dengan ortopati oleh karya integratif Roh Kudus (Archer, "Pentecostal," 309, catatan kaki no. 29). Kritik terhadap ortodoksi sebagai kebenaran pengetahuan saja juga telah diajukan oleh tokoh teologi pembebasan, yakni Gutierrez dan Jon Sobrino, yang menekankan peran praksis dalam membantu memahami kebenaran dengan lebih lengkap (lih. Charles Ringma, "The Church's Calling in A Troubled World: The Grand Design and 
elaborasi model ini dengan perspektif injili sembari berinteraksi dengan spektrum tradisi teologi yang tergabung di dalamnya (Reformed, Wesleyan, Pentakosta) dan di luarnya (Katolik).

Konsep "kebenaran" di dalam bahasa Yunani diekspresikan oleh kata "aletheia," "alethes" (benar), "alethos" (benar-benar), dan "alethein" (mengungkapkan kebenaran). ${ }^{52}$ Alkitab Perjanjian Baru merujuk Yesus dengan kata "alethes" (Mat. 22:16) untuk menunjukkan fidelitas pribadi Kristus yang mendasari kebenaran ajarannya. ${ }^{53}$ Meskipun Alkitab menyatakan bahwa kebenaran bersifat personal, ini tidak berarti kebenaran bersifat relatif. Kebenaran proposisional didasarkan kepada kebenaran personal Allah yang dipahami dengan keterlibatan pribadi yang mendalam di dalam pengenalan relasional dengan Allah yang firman-Nya dapat disandari dan dipercayai. ${ }^{54}$ Berkaitan dengan pascakebenaran, jawaban atas keputusasaan

Fragile Engagement," Zadok Papers 225/226 [2017]: 4-5). Sedangkan, peran emosi dalam beralih dari ide kepada praksis juga telah ditinjau dalam lingkaran Katolik (lih. Edward Collins Vacek, SJ, "Orthodoxy Requires Orthopathy: Emotions in Theology," Horizons 40/2 [2013]: 218). Namun, model ini sendiri telah ditinjau sebagai model etika injili yang memperhatikan aspek pemikiran, pemilihan, dan perasaan dalam mengomunikasikan berita Injil (Richard J. Mouw dan John H. Yoder, "Evangelical Ethics and the Anabaptist-Reformed Dialogue," The Journal of Religious Ethics 17/2 [1989]: 135).

52. Rider dan Peters, "Post-truth," 4.

53. Arthur F. Holmes, Segala Kebenaran adalah Kebenaran Allah (All Truth is God's Truth), terj. Yongky Karman dan Solomon Yo (Surabaya: Momentum, 2017), 63.

54. Bdk. Holmes, Segala Kebenaran, 64-65. Kaum injili memang berfokus kepada penerapan pribadi pengajaran untuk mengelola pengalaman subjektif atas kebenaran Alkitab yang objektif (Nancy Pearcey, Total Truth: Liberating Christianity from Its Cultural Captivity [Wheaton: Crossway, 2008], 253). 
eksistensial dan relativisme pascamodern adalah dengan kembali kepada pengertian yang alkitabiah dan integratif mengenai kebenaran proposisional (ortodoksi kekristenan) dan kebenaran personal yang ditemukan di dalam segenap pribadi dan karya Kristus (ortopati dan ortopraksi). ${ }^{55}$

Salah satu dari 14 kata dalam bahasa Yunani yang mengungkapkan konsep kebenaran adalah "orthos." ${ }^{56}$ Kata "orthos" secara denotatif berarti lurus atau tegak lurus dan secara metaforis bermakna benar (true, correct), nyata (real), asli (genuine), dan adil (just). ${ }^{57}$ Model yang diajukan mencakup ketiga aspek utama dari kehidupan iman murid Kristus (keyakinan, praktik, dan perasaan) yang mendapatkan makna benar, tepat, dan asli di dalam Tuhan Yesus yang diimani dan diikuti (Mat. 16:24). Karakteristik krusisentrisme dari teologi injili bersesuaian dengan model Ortodoksi-Ortopraksi-Ortopati yang berfokus kepada pribadi dan karya Kristus di mana setiap orang Kristen dipanggil untuk menjadi serupa dengan gambaran Kristus (Rm. 8:29).

Ortodoksi (Orthodoxy)

Istilah "ortodoksi" berasal dari dua kata Yunani, yaitu "ortho" berarti benar, tepat, lurus, atau tegak; dan "doxa" yang berarti

55. Bdk. Holmes, Segala Kebenaran, 84-85.

56. Rider dan Peters, "Post-truth," 4.

57. Henry George Liddell dan Robert Scott, A Greek-English Lexicon (Oxford: Clarendon, 1940), s.v. "ỏpӨóc." 
kepercayaan, kemuliaan atau ibadah. ${ }^{58}$ Sederhananya, istilah ortodoksi mengacu kepada keyakinan yang benar. ${ }^{59}$ Kaum injili berpegang kepada otoritas Alkitab, ketuhanan Kristus, keutamaan Injil dan penginjilan sebagai pengajaran yang menjadi ciri mendasar dari identitas teologis kaum injili. ${ }^{60}$ Kaum injili mengakui keberagaman pandangan di antara kaum injili sendiri terhadap doktrin-doktrin yang non-esensial, seperti: perihal karunia bahasa lidah dan karya Roh Kudus, relasi antara kehendak manusia dan providensia Allah (Calvinist, Arminian), dan kehadiran Kristus dalam sakramen (Lutheran, Zwinglian). ${ }^{61}$

Gereja seringkali memandang ortodoksi dalam pengertian sempit sebagai komitmen kepada kebenaran proposisional yang mengasumsikan pengetahuan tentang Allah yang diterima hanya

58. Lih. R. Paul Stevens, "Living Theologically: Toward A Theology of Christian Practice," Themelios 20/3 (1995): 4; Woodbridge, "Theological Triad," 4; Stone dan Duke, Think Theologically, 9.

59. Bolt menjabarkan spektrum pemahaman ortodoksi ke dalam empat kategori: kesetiaan institusional kepada gereja, ibadah yang benar, integritas pengakuan iman, dan ortodoksi sebagai ortopraksis (John Bolt, "The Problem of Polarization in the Christian Reformed Community," dalam Orthodoxy and Orthopraxis in the Reformed Community Today, ed. John Bolt, vol. 1, Christian Reformed Perspectives [Ontario: Paideia, 1986], 21-25). Penulis memaksudkan ortodoksi ke dalam kategori pengakuan iman atau pengajaran mendasar yang membentuk identitas teologis injili.

60. Otoritas Alkitab bagi kaum injili tidak hanya berhenti pada Allah yang mewahyukan firman-Nya, tetapi juga aktivitas Allah dalam proses penafsiran dan penerapan pribadi oleh pembaca (McGrath, Evangelicalism, 59). Keutamaan penginjilan terlihat dari dokumen Lausanne Covenant (1974) dan Cape Town Commitment (2010) yang menegaskan komitmen injili secara internasional (Ringma, "Church's Calling," 3 ).

61. Bdk. Stackhouse, "Evangelical," 56-57; McGrath, Evangelicalism, 59, 68-72. 
melalui proses mental secara kognitif. ${ }^{62}$ Sedangkan, Alkitab tidak dipandang kaum injili sekadar sumber berteologi sebagai pengetahuan abstrak semata, tetapi juga dasar bagi kehidupan kristiani, baik secara personal maupun korporat. ${ }^{63}$ Memang selalu ada ketegangan di dalam kaum injili sendiri antara apa yang disebut sebagai "skolastisisme" yang mengedepankan pemikiran dan pengajaran yang benar dengan "pietisme" yang mengutamakan relasi personal dengan Kristus yang transformatif. ${ }^{64}$ Namun, pengetahuan kognitif tentang Allah perlu dilengkapi dengan ortopraksis dan ortopati agar memiliki pengenalan yang utuh dan alkitabiah.

\section{Ortopraksi (Orthopraxy)}

Istilah "ortopraksi" atau "ortopraksis" (orthopraxis) berasal dari kata Yunani untuk praktik, yakni "praxis." ${ }^{\prime 5}$ Menurut Stevens, ortopraksi merupakan adalah "praktik-praktik yang harmonis dengan kerajaan Allah yang membawa nilai dan kebaikan ke dalam dunia." ${ }^{\prime 66}$ Ketegangan antara ajaran yang dipercayai dengan perilaku dalam kehidupan seharihari sebagai pengikut Kristus tidak dapat diabaikan. Kepercayaan iman Kristen merupakan dasar bagi praksis umat kristiani, sehingga teologi tidak sekadar hanya menjelaskan signifikansi siapa Allah dan apa yang

62. Woodbridge, "Theological Triad," 3.

63. McGrath, Evangelicalism, 57.

64. McGrath, "Evangelical," 18-19. Pearcey mengelompokkan kaum injili ke dalam sayap Methodis yang cenderung populis-pietis dan sayap Presbyterian yang scholarly-rational (Pearcey, Total Truth, 295-96).

65. Vacek, SJ, “Orthopathy," 220.

66. Stevens, "Living Theologically," 5. 
telah diperbuat-Nya, melainkan juga memperhatikan bagaimana teologi berurusan dengan klaim kebenaran-kebenaran tentang Allah demi sebuah cara kehidupan (for the sake of a way of life). ${ }^{67}$ Teologi Kristen merupakan suatu cara kehidupan yang didasarkan kepada Allah yang bertindak di dalam dunia ciptaan (theopraxis) sehingga praksis perlu menjadi integral dengan refleksi teologis ini. ${ }^{68}$

Dokumen-dokumen gerakan Lausanne yang mewakili evangelikalisme global memang tidak menggunakan istilah "ortodoksi" dan "ortopraksis" secara eksplisit, tetapi susunan isinya yang bergerak dari doktrin-doktrin inti Kristen menuju aplikasi menegaskan bahwa ada keterkaitan erat antara ortodoksi dan ortopraksis dalam biblisisme dan aktivisme gerakan injili. ${ }^{69}$ Menariknya, cara Paulus berteologi yang bergerak dari kepercayaan doktrin-doktrin (indikatif) kepada penerapan etis di dalam praktiknya (imperatif) bersesuaian dengan pemahaman bahwa teologi tidak dapat direduksi hanya sekadar ortodoksi iman Kristen tetapi juga mencakup cara kehidupan sebagai pengikut Kristus. ${ }^{70}$ Lagipula, orang Kristen tidak dibentuk secara teologis untuk mengetahui Allah hanya dengan membaca dan berpikir, tetapi juga dengan bertindak dan melayani lewat praksis kehidupan sehari-hari. ${ }^{71}$ Jadi, ortopraksis dapat menghubungkan karakteristik biblisisme kaum injili

67. Miroslav Volf, “Theology for a Way of Life," Ex Auditu 17 (2001): 136. Stevens menggunakan frasa "living theologically" untuk konsep ini (Stevens, "Living Theologically," 4).

68. Stiver, Life, 35.

69. Bdk. Ringma, "Church's Calling," 4.

70. Lih. Volf, "Theology," 137-38.

71. Stevens, "Living Theologically," 5. 
dengan aktivisme yang bertalian dengan pelayanan dan penginjilan sebagai implikasi imperatif dari otoritas Alkitab dalam kehidupan kaum injili.

\section{Ortopati (Orthopathy)}

Kata "ortopati" berasal dari kata "pathos" dalam bahasa Yunani yang berkaitan dengan hasrat, emosi, perasaan, simpati; atau secara harfiah mengacu kepada hasrat yang benar (right passion). ${ }^{72}$ Awalan "orto-" menunjukkan ada himpunan emosi yang baik atau benar sebagaimana ada kumpulan emosi yang salah atau buruk. ${ }^{73}$ Afeksi yang dimaksudkan merupakan kecenderungan (disposisi) dan bukan sekadar berbagai emosi dan perasaan yang tidak terkendali. ${ }^{74}$ Sifat "orto" dari afeksi Kristen pada hakikatnya ditentukan berdasarkan tanggapan terhadap kehidupan dan pengajaran Yesus Kristus: bagaimana hati (ortopati) mengarahkan apa yang diketahui (ortodoksi) dan bagaimana seseorang bertindak (ortopraksis) seperti yang didemonstrasikan Yesus. ${ }^{75}$ Menurut James K. A. Smith, manusia merupakan "makhluk berhasrat" (desiring animal) ketimbang sekadar makhluk berpikir sehingga identitas manusia ditentukan dari apa yang dicintai secara hakiki, yaitu visi kehidupan yang membentuk seluruh tindakan,

72. Lih. Ringma, "Church's Calling," 5; Stevens, "Living Theologically," 6.

73. Vacek, SJ, "Orthopathy," 220.

74. Sang-Ehil Han, Paul Louis Metger, dan Terry C. Muck, "Christian Hospitality and Pastoral Practices from an Evangelical Perspective," Theological Education 47/1 (2012): 24.

75. Han, Metger, dan Muck, "Hospitality," 24. 


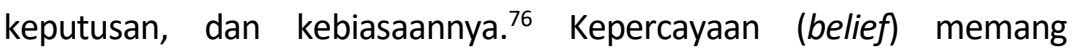
merupakan salah satu komponen dari iman yang hidup; namun tidak cukup hanya memiliki pengetahuan secara intelektual, tapi juga perlu melibatkan emosi, menghargai dan hidup di dalam relasi pengenalan akan Tuhan (knowing of God) ketimbang pengetahuan tentang Tuhan semata (knowing about God). ${ }^{77}$ McGrath, sembari mengutip pemikiran "knowing God" (J. I. Packer) dan "religious affections" (Jonathan Edwards), menegaskan aspek emosional-afektif dari pengetahuan teologis sebagai relasi dengan Allah, "Knowledge of God is not an academic matter but a relational reality." ${ }^{78}$ Jadi, ortopati juga memiliki bagian di dalam kehidupan spiritual kaum injili.

\section{Model Integratif: Cara Hidup Kaum Injili}

Ketimpangan antara kepercayaan terhadap pengajaran Alkitab dengan praksis kehidupan orang Kristen juga merupakan pergumulan eksistensialis yang dialami kaum injili. Seperti yang diungkapkan Miroslav Volf, tujuan teologi memang tidak berhenti hanya pada menyampaikan "pengetahuan" tentang Allah, tetapi melayani suatu cara hidup (a way of life). ${ }^{79} \quad$ Umat Kristen perdana sendiri tidak menyebut diri mereka sebagai "orang Kristen" melainkan sebagai para

76. James K. A. Smith, Desiring the Kingdom: Worship, Worldview, and Cultural Formation (Grand Rapids: Baker Academic, 2009), 26. Untuk hubungan disposisi emosional dengan praktik liturgi, lih. Smith, Desiring the Kingdom, bab $1-2$.

77. Stone dan Duke, Think Theologically, 9.

78. McGrath, "Evangelical," 23.

79. Volf, "Theology," 126. 
pengikut "Jalan [Tuhan]" (Kis. 9:2), karena keselamatan mencakup telah mengikut Sang Jalan (masa lampau), terus menerus mengikut (masa kini) sampai akhirnya tiba di tujuan (masa depan). ${ }^{80}$

Ketiga elemen yang telah dijabarkan di atas tidak dimaksudkan untuk dipahami secara fragmentatif. Penulis mengusulkan suatu model kehidupan berteologi yang integratif yang merangkul aspek-aspek kepercayaan (ortodoksi) iman Kristen, praksis kehidupan sebagai pengikut Kristus (ortopraksi), dan hasrat yang menyerupai dan memancarkan keindahan Kristus (ortopati). Teologi tidak dapat dipisahkan dari kehidupan iman sebagai umat Kristen, sebab teologi tidak hanya membentuk kepercayaan-kepercayaan eksplisit kita tetapi juga sikap-sikap dan emosi yang tidak sadar. ${ }^{81}$ Ketimpangan salah satu aspek dalam model ini akan berdampak negatif. Ortodoksi dan ortopraksi tanpa disertai ortopati akan menjadi perilaku pragmatis dan formalistik. Ortopraksi dan ortopati tanpa dilengkapi ortodoksi akan menuju kepada tindakan yang serampangan. Ortodoksi dan ortopati tanpa disertai ortopraksi menghasilkan pengetahuan dan niat baik tanpa ada aksi nyata. Baik kepala, tangan, maupun hasrat kita perlu saling melengkapi untuk memancarkan kebenaran, kebaikan, dan keindahan Kristus di dalam diri kita sebagai murid Kristus. ${ }^{82}$ Dengan kata lain, ketiga elemen tersebut saling berkelindan di dalam model kehidupan berteologi yang integratif.

80. Stiver, Life, 307.

81. Stiver, Life, 2.

82. Analogi "head, hand and heart" ini dipinjam dari Ringma, "Church's Calling," 5. 
Ortodoksi, ortopraksis dan ortopati bukan sekadar menyampaikan kepercayaan, perilaku, dan perasaan yang sesuai dengan kebenaran yang dinyatakan di dalam Alkitab dan berpusatkan kepada Kristus. Model ini juga merangkul aspek keindahan (beauty) dan kebaikan (goodness) yang dipancarkan dari ketiga elemen dalam model tersebut karena berakar dalam relasi dengan Yesus Kristus yang benar, baik, dan indah. Klaim Yesus sebagai "Kebenaran" (Yoh. 14:6) tidak dimaksudkan untuk dipahami sebatas Kristus benar secara proposisional, sebab "Kebenaran" yang dimaksudkan memiliki aspek personal sebagaimana aspek kognitif dalam konteks ini. ${ }^{83}$ Berkaitan dengan ini, kaum injili menekankan penerapan pribadi dari iman secara relasional dengan "Kebenaran" yang memengaruhi keberadaan terdalam diri. ${ }^{84}$ Injil bukan sekadar kumpulan proposisi yang "benar secara objektif" tentang Kristus, tetapi juga mencakup seluruh pribadi dan karya Kristus sendiri. ${ }^{85}$ Karena itu, model Ortodoksi-Ortopraksi-Ortopati berpusatkan kepada Yesus Kristus sehingga setiap kaum injili perlu mengejawantahkan kehidupannya dalam mengikut Kristus secara integratif. Di dunia pascakebenaran, relevansi teologi Kristen bagi masyarakat (kompilasi kebenaran, keindahan, dan kebaikan yang koheren di dalam Kristus) dan relevansi terhadap seluruh aspek kehidupan manusia (tidak rasio semata, praksis atau pun emosi semata) perlu ditunjukkan sebagai cara

83. McGrath, Passion, 177.

84. McGrath, Evangelicalism, 73-74.

85. McGrath, Passion, 178. 
kehidupan integratif yang menyerupai Kristus (model OrtodoksiOrtopraksi-Ortopati). ${ }^{86}$

\section{Berteologi di Dunia Post-Truth dengan Model Ortodoksi-Ortopraksi- Ortopati}

Keyakinan teologis yang dimiliki seseorang perlu berhubungan dengan praksis kehidupan sehari-hari dan relevan dalam memproklamasikan pesan Allah bagi dunia masa kini. ${ }^{87}$ Sebagaimana Kristus berinkarnasi memasuki tempat dan waktu tertentu dalam dunia ini, demikian juga kaum injili perlu memperhatikan tempat dan zaman dalam berteologi. ${ }^{88}$ Dengan model Ortodoksi-Ortopraksi-Ortopati, kaum injili dapat menunjukkan cara kehidupan murid Kristus dalam menghadapi pascakebenaran. Penulis akan membahas implementasi model Ortodoksi-Ortopraksi-Ortopati dalam menanggapi tiga masalah berkaitan dengan pascakebenaran, yakni: epistemologi antara perasaan dan fakta, menanggapi misinformation dengan literasi media sosial, dan menanggapi tribalisme dengan mengasihi sesama.

Epistemologi antara Perasaan dan Fakta

Barna mencatat salah satu karakter masyarakat pascakebenaran ialah "a battle between feelings and facts" (pertarungan antara

86. Bdk. kesimpulan Diogenes Allen seperti dikutip di McGrath, Passion, 188-89.

87. Bdk. Volf, "Theology," 137; Stone dan Duke, Think Theologically, 35.

88. Bdk. Veeneman, Introducing, 10. 
perasaan dan fakta). ${ }^{89}$ Seseorang cenderung mudah mempercayai informasi apa pun karena telah memiliki preferensi atau dukungan emosional terhadap hal itu dan tidak memverifikasi terlebih dahulu kebenarannya. ${ }^{90}$ Hasil survei Barna terhadap siapa yang menjadi sumber berita yang kredibel adalah $39 \%$ wartawan, tetapi disusul tipis oleh diri sendiri sebesar 32\% (mempercayai insting pribadi daripada orang lain) serta teman, keluarga, dan rekan sebesar $27 \% .{ }^{91}$ Bias konfirmasi juga ditunjukkan dengan kecenderungan menerima informasi yang menguatkan keyakinannya daripada menguji kebenaran informasi tersebut. ${ }^{92}$ Aspek ortodoksi Alkitab mengajar kita untuk menerima kebenaran dan fakta (sekalipun itu tidak membuat diri merasa lebih nyaman) dan juga hikmat untuk membedakan mana yang benar dan baik dengan mana yang salah dan jahat (bdk. 2 Tim. 3:16; Ams. 17:15; 1 Raj. 3:9; Yes. 5:20).

Barna Group mengajukan pertanyaan berkenaan dengan pascakebenaran, "Dapatkah kamu mengetahui kebenaran atau merasakan kebenaran?"93 Kebenaran tidak dipahami sekadar proposisi di dalam ortodoksi Alkitab, tetapi juga merujuk aspek relasional dari kebenaran yang bersandar kepada Allah di dalam Kristus. Yesus sebagai Sang Kebenaran (Yoh. 14:6) merupakan Pribadi yang dapat dirasakan dan dikenali di dalam relasi yang dikaryakan Roh Kudus atas orang

89. Barna Group, "Post-Truth," 118.

90. Juditha, "Literasi," 79; Lewandowsky, Ecker, dan Cook, "Misinformation," 29.

91. Barna Group, "Post-Truth," 120.

92. Bdk. Golose, "Strategi," 10.

93. Barna Group, "Post-Truth," 119. 
Kristen (ortopati) dan berimplikasi imperatif agar murid-murid-Nya mengasihi kebenaran dan sesama (ortopraksis). Meminjam ide Baggini, penghiburan kita dalam dunia pascakebenaran adalah kebanyakan orang masih menghargai kedua kebajikan kebenaran (meliputi: ketulusan dan akurasi) yang mengarahkan kepada relasi yang benar antara pencari kebenaran dengan dunia, "to get our facts right we need to get our attitudes to the facts right." ${ }^{\prime 4}$ Di dalam Kristus, kaum injili diajar untuk memiliki ortopati (sikap hati yang tepat) terhadap faktafakta dan tidak membiarkan perasaan tidak nyaman yang menentukan epistemologinya dengan bias konfirmasi.

\section{Literasi Media Sosial}

Di tengah maraknya informasi yang keliru dan berita bohong, kita memerlukan kemampuan literasi informasi di samping literasi Alkitab yang sering ditekankan sebagai karakteristik kaum injili. Ortodoksi Alkitab mengajar kita untuk menguji segala sesuatu (bdk. 1Tes. 5:21, 1 Yoh. 4:1). Implikasi praktisnya adalah kita perlu memastikan terlebih dahulu kebenaran informasi yang akan dibagikan kepada orang lain dan memastikan manfaatnya sebelum menyebarkannya. ${ }^{95}$ Literasi media mencakup kemampuan kritis untuk memaknai pesan, memverifikasi pesan serta mengonstruksi pesan positif dan mendistribusikannya

94. Baggini, Truth, loc. 749.

95. Bdk. Vibriza Juliswara, “Mengembangkan Model Literasi Media yang Berkebhinnekaan dalam Menganalisis Informasi Berita Palsu (Hoax) di Media Sosial," Jurnal Pemikiran Sosiologi 4/2 (2017): 144. 
kepada pihak lain. ${ }^{96}$ Literasi informasi yang memadai dapat menghindarkan publik dari perilaku cepat mempercayai berita-berita yang tidak jelas kebenarannya. ${ }^{97}$ Dengan motif kasih (ortopati) terhadap kebenaran informasi yang dibagikan, kita turut membangun budaya literasi informasi yang sehat di tengah masyarakat yang dilanda pascakebenaran. Jadi, aspek fakta maupun perasaan diperlukan dalam hikmat (discernment) agar dapat mengasihi kebenaran dan sesama. ${ }^{98}$

Mengasihi Sang Liyan sebagai Sesama

Baggini juga mengkritik kecenderungan pascakebenaran dalam diri orang-orang yang berkumpul dengan orang-orang yang sepaham (the like-minded) untuk mengutamakan jejaring kepercayaan yang menyimpang dan mengabaikan serta menyangkali fakta-fakta yang tidak menyenangkan. ${ }^{99}$ Mengenai tribalisme, Barna Group menyatakan bahwa orang-orang cenderung mempercayai apa yang dipercayai kelompok mereka sendiri, sekalipun bukti atau opini eksternal bertentangan dengan keyakinannya. Tribalisme menjadi salah satu ancaman paling berbahaya bagi masyarakat pascakebenaran, karena menghalangi kelompok-kelompok untuk menyambut, mempertimbangkan, atau belajar dengan kelompok-kelompok yang berbeda dengannya. ${ }^{100}$ Model Ortodoksi-Ortopraksi-Ortopati dapat

96. Selengkapnya, lih. Juliswara, "Literasi Media," 151; Juditha, "Literasi," 82-83.

97. Juditha, "Literasi," 79.

98. Barna Group, “Post-Truth,” 119.

99. Baggini, Truth, loc. 734.

100. Barna Group, "Post-Truth," 121. 
dipakai untuk mengasihi "sang liyan" (the others) sebagai sesama manusia sebagaimana ajaran Kristus.

Kegaduhan retorika pascakebenaran yang terjadi di media sosial yang menggunakan sentimen identitas dan diskriminasi berbau SARA (Suku, Agama, Ras, dan Antargolongan) dapat melunturkan dan mendekonstruksi semangat kemajemukan atau kebinekaan yang menjadi landasan masyarakat Indonesia dalam berbangsa. ${ }^{101}$ Kasus yang baru-baru ini terjadi adalah kerusuhan di Manokwari yang terprovokasi dengan konten hoax yang disebarkan oleh akun media sosial yang mengembangkan narasi diskriminasi dan kekerasan terhadap mahasiswa Papua. ${ }^{102}$ Mahasiswa-mahasiswa Papua menjadi sang liyan yang seolah-olah diperlakukan bukan sebagai bagian dari saudara sebangsa. Lalu, bagaimana merawat kebinekaan dalam konteks kehidupan berbangsa di Indonesia?

Dalam konteks multireligius, orang Kristen tidak hanya perlu mengeksegesis teks Alkitab tetapi juga konteks religius agar dapat mengomunikasikan Injil dengan efektif. ${ }^{103}$ Perjumpaan tokoh-tokoh Alkitab dengan sang liyan menunjukkan pendekatan yang beragam, di antaranya: mengontraskan kebenaran dengan kesalahan (Elia di 1Raj. 18), mencari dasar bersama untuk menyatakan kebenaran (Paulus kepada orang Atena di Kis. 17), dan menggunakan konsep tradisi yang

101. Bdk. Juliswara, "Literasi Media," 143; Golose, "Strategi."

102. Lih. "Polri Telusuri Akun Medsos yang Picu Provokasi Rusuh di Manokwari," Detik, 2019, diakses 14 September 2019, https://news.detik.com/berita/d-4671478/polri-telusuri-akun-medsos-yangpicu-provokasi-rusuh-di-manokwari.

103. Han, Metger, dan Muck, "Hospitality," 17. 
lain untuk mengomunikasikan kebenaran Injil (Yohanes menggunakan konsep logos di Yoh. 1). ${ }^{104}$ Sebagaimana perumpamaan orang Samaria yang murah hati, kaum injili perlu mengundang sang liyan untuk turut berbagi dalam kehidupan bersama sebagai saudara sebangsa selaras dengan keramahan dan kasih murid Kristus kepada sesama yang berakar dari relasi kasih dengan Kristus. ${ }^{105}$ Hospitalitas umat Kristen dapat didemonstrasikan melalui ortodoksi (bagaimana Kristus mengajar mengasihi sesama manusia), ortopraksis (bagaimana kasih Kristus mewujud dalam tindakan nyata dalam mengasihi sesama), dan ortopati (bagaimana kemurahan hati dan kasih Kristus terpancar indah dalam afeksi kita). ${ }^{106}$

Kiranya Allah Tritunggal memampukan kaum injili di Indonesia untuk dapat menghidupi teologinya dengan model OrtodoksiOrtopraksi-Ortopati dalam menghadapi pascakebenaran.

104. Han, Metger, dan Muck, "Hospitality," 16.

105. Bdk. Han, Metger, dan Muck, "Hospitality," 26.

106. Bdk. Han, Metger, dan Muck, "Hospitality," 26. 


\section{Bibliografi}

Allen, Paul. Theological Method: A Guide for the Perplexed. New York: Continuum, 2012.

Archer, Kenneth J. "A Pentecostal Way of Doing Theology: Method and Manner." International Journal of Systematic Theology 9/3 (Juli 2007): 301-14.

Baggini, Julian. A Short History of Truth: Consolations for A Post-Truth World. edisi Kindle. London: Quercus, 2017.

Barna Group. "The Truth about a Post-Truth Society: Barna Identifies Five Reasons the World Is No Longer in Agreement about Anything." Dalam Barna Trends 2018: What's New and What's Next at the Intersection of Faith and Culture. Grand Rapids: Baker, 2017.

Bolt, John. "The Problem of Polarization in the Christian Reformed Community." Dalam Orthodoxy and Orthopraxis in the Reformed Community Today. Disunting oleh John Bolt. Vol. 1. Christian Reformed Perspectives. Ontario: Paideia, 1986.

Golose, Petrus R. "Strategi Penanganan Firehose of Falsehood pada Era Post-Truth (Kajian dalam Rangka Menyukseskan Pemilu 2019)." Jurnal IImu Kepolisian 13/1 (2019): 6-15.

Han, Sang-Ehil, Paul Louis Metger, dan Terry C. Muck. "Christian Hospitality and Pastoral Practices from an Evangelical Perspective." Theological Education 47/1 (2012): 11-31.

Holmes, Arthur F. Segala Kebenaran adalah Kebenaran Allah (All Truth is God's Truth). Diterjemahkan oleh Yongky Karman dan Solomon Yo. Surabaya: Momentum, 2017.

Juditha, Christiany. "Literasi Informasi Melawan Hoaks Bidang Kesehatan di Komunitas Online." Jurnal Ilmu Komunikasi 16/1 (Juni 2019): 77-90.

Juliswara, Vibriza. "Mengembangkan Model Literasi Media yang Berkebhinnekaan dalam Menganalisis Informasi Berita Palsu (Hoax) di Media Sosial." Jurnal Pemikiran Sosiologi 4/2 (2017): 142-164.

Larsen, Timothy. "Defining and Locating Evangelicalism." Dalam The Cambridge Companion to Evangelical Theology. Disunting oleh Timothy Larsen dan Daniel J. Treier, 1-14. Cambridge Companions to Religion. Cambridge: Cambridge University Press, 2007. 
Levitin, Daniel J. Weaponized Lies: How to Think Critically in the PostTruth Era. Google Play Books. Dutton, 2017.

Lewandowsky, Stephan, Ullrich K. H. Ecker, dan John Cook. "Beyond Misinformation: Understanding and Coping with the 'Post-truth' Era." Journal of Applied Research in Memory and Cognition (2017): 1-57.

Liddell, Henry George, dan Robert Scott. A Greek-English Lexicon. Oxford: Clarendon, 1940.

McGrath, Alister E. A Passion for Truth: The Intellectual Coherence of Evangelicalism. Leicester: Apollos, 1997.

. "Evangelical Theological Method: The State of the Art." Dalam Evangelical Futures: A Conversation on Theological Method, disunting oleh John G. Stackhouse, 15-37. Grand Rapids: Baker, 2000.

. Evangelicalism \& the Future of Christianity. Downers Grove: InterVarsity, 1995.

McIntyre, Lee C. Post-Truth. The MIT Press Essential Knowledge Series. Cambridge: MIT Press, 2018.

Mouw, Richard J., dan John H. Yoder. "Evangelical Ethics and the Anabaptist-Reformed Dialogue." The Journal of Religious Ethics 17/2 (1989): 121-37.

Noll, Mark A. Skandal Pemikiran Injili. Diterjemahkan oleh Sudi Ariyanto. Surabaya: Momentum, 2008.

Pearcey, Nancy. Total Truth: Liberating Christianity from Its Cultural Captivity. Wheaton: Crossway, 2008.

Rider, Sharon, dan Michael A. Peters. "Post-truth, Fake News: Viral Modernity and Higher Education." Dalam Post-Truth, Fake News. Disunting oleh Michael A. Peters, Sharon Rider, Mats Hyvönen, dan Tina Besley. Singapura: Springer, 2018.

Ringma, Charles. "The Church's Calling in A Troubled World: The Grand Design and Fragile Engagement." Zadok Papers 225/226 (2017): 2-8.

Smith, James K. A. Desiring the Kingdom: Worship, Worldview, and Cultural Formation. Grand Rapids: Baker Academic, 2009.

Stackhouse, John G. "Evangelical Theology Should Be Evangelical." Dalam Evangelical Futures: A Conversation on Theological 
Method. Disunting oleh John G. Stackhouse, 39-58. Grand Rapids: Baker, 2000.

Stevens, R. Paul. "Living Theologically: Toward A Theology of Christian Practice." Themelios 20/3 (1995): 4-8.

Stiver, Dan R. Life Together in the Way of Jesus Christ: An Introduction to Christian Theology. Waco: Baylor University Press, 2009.

. "Theological Method." Dalam The Cambridge Companion to Postmodern Theology. Disunting oleh Kevin J. Vanhoozer. Cambridge Companions to Religion. Cambridge: Cambridge University Press, 2003.

Stone, Howard W., dan James O. Duke. How to Think Theologically. Edisi ke-2. Minneapolis: Fortress, 2006.

Vacek, SJ, Edward Collins. "Orthodoxy Requires Orthopathy: Emotions in Theology." Horizons 40/2 (2013): 218-41.

Veeneman, Mary M. Introducing Theological Method: A Survey of Contemporary Theologians and Approaches. Grand Rapids, Michigan: Baker Academic, 2017.

Volf, Miroslav. "Theology for a Way of Life." Ex Auditu 17 (2001): 125-41. Woodbridge, N. B. "Living Theologically-Towards A Theology of Christian Practice in Terms of the Theological Triad of Orthodoxy, Orthopraxy and Orthopathy as Portrayed in Isaiah 6:1-8: A Narrative Approach." HTS Teologiese Studies/Theological Studies 66/2, Art. \#807 (2010).

Zackariasson, Ulf. "Introduction: Engaging Relativism and Post-Truth." Dalam Relativism and Post-truth in Contemporary Society: Possibilities and Challenges. Disunting oleh Mikael Stenmark, Steve Fuller, dan Ulf Zackariasson. New York: Springer, 2018.

"Jebakan Hoaks Ratna Sarumpaet." Tempo, 2018. Diakses 14 September 2019. https://kolom.tempo.co/read/1133717/jebakan-hoaksratna-sarumpaet.

"Polri Telusuri Akun Medsos yang Picu Provokasi Rusuh di Manokwari." Detik, 2019. Diakses 14 September 2019. https://news.detik.com /berita/d-4671478/polri-telusuri-akun-medsos-yang-picu-provo kasi-rusuh-di-manokwari.

"The War on Hoaxes." The Jakarta Post, 2018. Diakses 14 September 2019. https://www.thejakartapost.com/academia/2018/10/09/ the-war-on-hoaxes.html. 